\title{
JUURNAL.RU
}

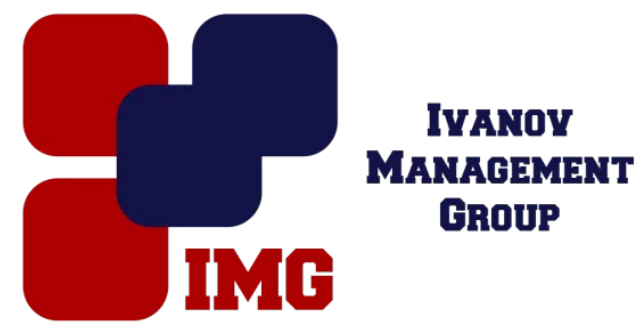

Яскевич И.Н. Наииональный исследовательский Томский государственный университет

Томск, Россия

doi: 10.18411/lj-31-01-2017-3-10

idsp 000001:lj-31-01-2017-3-10

\section{Исследование инновационного потенциала обучающихся художественного профиля: к постановке проблемы}

\section{Аннотация}

В статье актуализирована проблема диагностики будущих специалистов в области художественного образования. Дано определение инновационного потенциала личности. Обсуждается опыт кафедры дизайна НИ ТГУ в научнометодическом сопровождении процесса подготовки обучающихся художественного профиля.

Ключевые слова: инновационный потенциал обучающихся, художественное образование.

\section{Abstract}

In article the problem of diagnostics of future experts in the field of art education is staticized. Definition of innovative potential of the personality is given. Experience of department of design of TSU in scientific and methodical maintenance of process of training of students of an art profile is discussed.

Keywords: innovative potential of students, art education.

Вопрос подготовки кадров в области художественного образования на сегодняшний день является как никогда открытым и актуальным. Принятие нового Закона об образовании, изменение системы подготовки специалистов (переход на многоуровневую систему бакалавриат - магистратура), переход на дополнительные предпрофессиональные общеобразовательные программы, введение профессиональных стандартов - актуализировали вопросы профориентационной и психолого-педагогической диагностики выбора будущего профиля обучения.

Ситуация в современном образовании характеризуется увеличивающейся эклектичностью, разрозненностью требований к подготовке специалистов художественного образования. Университеты сегодня меняются стремительно. Реализация проекта 5 - 100 обозначила не только концептуальный переход к «Университетам 4.0», но и ожидания социума - производство инноваций и трансфер знаний в экономику. Художественное образование, в этом ключе, 
является основой для развития таких направлений как промышленный дизайн, урбанистика и пр. Эти отрасли знаний в настоящий момент находятся на «волне развития», а, следовательно, требуют особого пристального внимания к отбору обучающихся и специалистов. Новизна данного исследования заключается в том, что принципиально изменяется ракурс формирования профессионально значимых качеств обучающихся в области художественного образования - инновационный потенциал личности. Согласно исследованиям В.Е. Клочко и Э.В. Галажинского (2009) под инновационным потенциалом понимается интегральная системная характеристика человека, которая будет определять его способности: 1) обеспечивать режим саморазвития как стратегического фактора жизнеосуществления; 2) генерировать новые формы поведения и деятельности, которые способствуют ценностно-смысловым изменениям жизненного пространства личности[2].

Работа в этом направлении системно ведется в Институте искусств и культуры [3, 5] и на факультете психологии ТГУ [1, 4]c 2006г. В них художественное образование понимается как среда обеспечивающая обучение, развитие личности содержит значительный потенциал, позволяющий расширять обучающемуся контексты осмысления себя и своих собственных действий. Наше предположение заключается в том, что среда художественного образования привлекательна для обучающихся, которые демонстрируют предпочтение к инновационной деятельности. Для проверки данной гипотезы используется опросник «Психологическая готовность к инновационной деятельности (В.Е. Клочко, О.М. Краснорядцева)[4]. Выявление психологической готовности к инновационной деятельности происходит через показатели - инициативность, предпочтение деятельности, требующей инновативности и готовности к переменам.

Таким образом, отбор будущих абитуриентов для художественного образования должен основываться не только на уже сложившихся представлениях о развитии творческого потенциала, но и инновационного потенциала личности

\section{Литература}

1. Абакумова Н.Н. Организация среды профессионального самоопределения: предпрофильная подготовка и профильное обучение // Вестник Томского государственного университета. - 2007. - № 296. - С. 194 - 199.

2. Галажинский Э.В., Клочко В.Е. Психология инновационного поведения. - Томск: Издательство Томского университета, 2009. - 240 с.

3. Долгих Н.А. Становление образа мира художника-педагога в процессе художественного образования // Вестник Томского государственного университета. Философия. Социология. Политология. - 2008. - № 3. C. $117-122$.

4. Клочко В.Е., Краснорядцева О.М., Мацута В.В. и др. Психодиагностические технологии выявления потенциала инновационности и одаренности молодежи: учеб.пособие. - Томск: Издательский дом Томского государственного университета, 2013. - 172 с.

5. Протасова Е.К., Абакумова Н.Н. Недостатки в системе отбора талантливой молодежи и пути их устранения // Управление талантами и трансформация корпоративной культуры: материалы международной конференции / под ред. О.Б. Алексеева, Э.В. Галажинского, А.О. Зоткин, 2016. - С. 233 - 236. 